University of Wyoming College of Law

Law Archive of Wyoming Scholarship

2-18-2015

\title{
Playing with the Pieces: Postmodernism in the Lawyer's Toolbox
}

Stephen Matthew Feldman

University of Wyoming College of Law, sfeldman@uwyo.edu

Follow this and additional works at: https://scholarship.law.uwyo.edu/faculty_articles

\section{Recommended Citation}

Feldman, Stephen Matthew, "Playing with the Pieces: Postmodernism in the Lawyer's Toolbox" (2015).

Faculty Articles. 112.

https://scholarship.law.uwyo.edu/faculty_articles/112

This Article is brought to you for free and open access by the UW College of Law Faculty Scholarship at Law Archive of Wyoming Scholarship. It has been accepted for inclusion in Faculty Articles by an authorized administrator of Law Archive of Wyoming Scholarship. 


\title{
ESSAY
}

\section{PLAYING WITH THE PIECES: POSTMODERNISM IN THE LAWYER'S TOOLBOX}

\author{
Stephen M. Feldman ${ }^{*}$
}

All that remains to be done is to play with the pieces. Playing with the pieces-that is post-modern.

Jean Baudrillard ${ }^{\mathbf{1}}$

$\mathrm{F}$

OR over a century, modernist scholars have constructed legal arguments by earnestly invoking lawyerly tools such as stare decisis, logical consistency, and original intent. ${ }^{2}$ Many scholars have assumed that these tools can be used as legitimate means for achieving goals justified either as substantively objective or as determined through some neutral processes. ${ }^{3}$ Recently, however, postmodern scholars have questioned the normative foundations for this view of the lawyer's toolbox. Goals, they argue, are never

* Professor of Law and Political Science, University of Tulsa; National Endowment for the Humanities Fellow, 1998. I thank Jim Mooney, Jay Mootz, Dennis Patterson, Pierre Schlag, Larry Catá Backer, and Marty Belsky for their helpful comments on earlier drafts. I also appreciate the financial support of the Faculty Summer Research Grant Program of the University of Tulsa College of Law.

' Jean Baudrillard, Game With Vestiges, 5 On Beach 19, 24 (1984).

2 For a discussion of the initial emergence of modernist legal scholarship, see Stephen M. Feldman, From Premodern to Modern American Jurisprudence: The Onset of Positivism, 50 Vand. L. Rev. 1387, 1417-46 (1997) [hereinafter Feldman, From Premodern]. For a discussion of the various stages of modernist scholarship, see Stephen M. Feldman, From Modernism to Postmodernism in American Legal Thought: The Significance of the Warren Court, in The Warren Court: A Retrospective 324, 329-44 (Bernard Schwartz ed., 1996) [hereinafter Feldman, From Modernism]. I will elaborate these discussions of modernism, and also discuss premodernism and postmodernism, in a forthcoming book: Stephen M. Feldman, A Science Most Sublime? American Legal Thought From Premodernism to Postmodernism (forthcoming 1999).

${ }^{3}$ See Herbert Wechsler, Towvard Neutral Principles of Constitutional Law, 73 Harv. L. Rev. 1, 10-20 (1959). 
objective or neutrally determined; rather, all substantive ends and legal processes reflect distinctive cultural values and social positions. ${ }^{4}$

Interestingly, some modernist scholars have partially accepted this postmodern insight. These scholars acknowledge that neutral baselines do not truly ground lawyerly arguments and judicial decisionmaking. Yet, these scholars in the end always somehow reach a modernist conclusion; often, through some slight of hand, they deem a particular result objectively desirable or justified. Thus, they manage to avoid the most troubling aspects of postmodern theory such as the deconstruction of textual meaning and the poststructural fixation on the pervasiveness of power. They domesticate postmodern insights by putting them in the lawyer's toolbox, to be taken out and used only when needed.

Even more interestingly, perhaps, postmodern scholars come close to replicating this modernist move. They use their postmodern insights to critique modernist arguments and positions, but they then fail to follow the implications of postmodernism to its outer reaches. In this Essay, I argue that these postmodernists are not lacking in nerve or perspicacity but rather that they are themselves enmeshed within the structures of scholarly and lawyerly discourse. As such, they must construct narratives and arguments that use the available rhetorical tools or modes of discourse-namely, they must use modernist and postmodernist concepts to present their views. But whereas modernist scholars use similar tools with earnestness (an earnestness, however, often accompanied by anxiety), postmodernist scholars use these tools with irony. Postmodernists use the tools despite knowing that they cannot perform as promised; in particular, modernist tools cannot deliver any indubitably grounded results. Yet for the postmodernists, no other options exist.

\footnotetext{
${ }^{4}$ See Stephen M. Feldman, The Politics of Postmodern Jurisprudence, 95 Mich. L. Rev. 166, 174-75, 185-87 (1996) [hereinafter Feldman, The Politics] (discussing how both Hans-Georg Gadamer and Jacques Derrida maintain that tradition or culture shapes one's prejudices and interests); Stephen M. Feldman, The Persistence of Power and the Struggle for Dialogic Standards in Postmodern Constitutional Jurisprudence: Michelman, Habermas, and Civic Republicanism, 81 Geo. L.J. 2243, 2258-66 (1993) [hereinafter Feldman, The Persistence of Power] (emphasizing that the enabling and distortive effects of power are always present); see also Stephen M. Feldman, Diagnosing Power: Postmodernism in Legal Scholarship and Judicial Practice (With an Emphasis on the Teague Rule Against New Rules in Habeas Corpus Cases), 88 Nw. U. L. Rev. 1046 (1994) [hereinafter Feldman, Diagnosing Power] (focusing on the themes of power and postmodernism).
} 
There are no other rhetorical or discursive devices that can be grasped. In this sense, then, postmodern scholarship amounts to playing with the pieces-even the fallen pieces that remain from deconstructed modernist positions..$^{5}$

Part I of this Essay explores how leading modernist scholars incorporate postmodern insights as instrumental tools in their arguments. Part II examines how postmodern scholars perform in a similar fashion. In particular, Part II focuses on a leading postmodern jurisprudent, Pierre Schlag. In a recent issue of the Harvard Law Review, Schlag deconstructed Langdellian legal science, the progenitor of modernist legal scholarship, by analogizing it to the science of phrenology, the now-disreputable study of skull shapes as an indicator of character and mental capacity. ${ }^{6}$ Part II begins by examining Schlag's deconstruction of Langdellian legal science and then continues by deconstructing Schlag's deconstruction. Part III, the Conclusion, explains how even the most unmitigated of postmodernists inevitably use postmodern insights as if they were tools or instruments.

Before proceeding, one point should be clarified. The distinction between modernism and postmodernism in legal scholarship is highly complex, yet for the purposes of this Essay, I do not need to explore this problem in depth.' It is sufficient to recognize that

sIn a similar vein, Andreas Huyssen writes that, in the 1970 s, there was "an ever wider dispersal and dissemination of artistic practices all working out of the ruins of the modernist edifice, raiding it for ideas, plundering its vocabulary and supplementing it with randomly chosen images and motifs from pre-modern and non-modern cultures as well as from contemporary mass culture." Andreas Huyssen, Mapping the Postmodern, 33 New German Critique 5, 25 (1984).

"See Pierre Schlag, Law and Phrenology, 110 Harv. L. Rev. 877 (1997).

'For a discussion of the differences between modernist and postmodernist scholarship, see Feldman, From Modernism, supra note 2, at 329-52. Sources that helpfully discuss the transitions from premodernism to modernism, in general, include Richard $\mathrm{J}$. Bernstein, Beyond Objectivism and Relativism: Science, Hermeneutics, and Praxis (1983); Hans Blumenberg, The Legitimacy of the Modern Age (Robert M. Wallace trans., MIT Press 1983) (1966); Louis Dupré, Passage to Modernity: An Essay in the Hermeneutics of Nature and Culture (1993); Karl Löwith, Meaning in History: The Theological Implications of the Philosophy of History (1949); Richard H. Popkin, The History of Scepticism From Erasmus to Spinoza (1979); Richard Rorty, Philosophy and the Mirror of Nature (1979); Richard Tarnas, The Passion of the Western Mind: Understanding the Ideas that Have Shaped our World View (1991); Stephen Toulmin, Cosmopolis: The Hidden Agenda of Modernity (1990); Eric Voegelin, The New Science of Politics: An Introduction (1987). Helpful sources on postmodernism in general include Zygmunt Bauman, Intimations of Postmodernity (1992); Steven 
most modernist scholars expressly articulate and defend normative values and goals, while postmodern scholars rarely do so. ${ }^{8}$ Modernists typically respond to some specified legal and social problem by recommending, for example, that Congress enact some proposed statute or that the Supreme Court adopt some doctrinal framework. Postmodernists refrain from such explicit normative recommendations, but they are neither politically apathetic nor unmindful of the possibility that their words might influence others. Postmodernists seek to intervene in ways other than overtly recommending particular social or legal changes. Thus, to be clear, postmodernists might be said to be playing with scholarly tools or pieces, but such play is not necessarily frivolous (though sometimes it can be); much postmodern scholarship is politically and morally charged.'

\section{LOOKING IN THE LAWYER'S TOOLBOX}

Modernist lawyers and scholars carry a toolbox containing devices such as stare decisis, logical consistency, the plain meaning of the text, the intentions of the framers or the parties, policy arguments, and balancing tests. ${ }^{10}$ Modernists reach in and pull out the tools they need to suit their particular instrumental purposes, to construct arguments for or against certain substantive positions. Learning to choose the right tools and to use them well is part of

Connor, Postmodernist Culture: An Introduction to Theories of the Contemporary (1989); Feminism/Postmodernism (Linda J. Nicholson ed., 1990); David Harvey, The Condition of Postmodernity: An Enquiry into the Origins of Cultural Change (1989); Fredric Jameson, Postmodernism, or, The Cultural Logic of Late Capitalism (1991); Jean-François Lyotard, The Postmodern Condition: A Report on Knowledge (Geoff Bennington \& Brian Massumi trans., Manchester Univ. Press 1984) (1979); Christopher Norris, What's Wrong With Postmodernism (1990); Postmodernism and Society (Roy Boyne \& Ali Rattansi eds., 1990); Leslie Paul Thiele, Thinking Politics: Perspectives in Ancient, Modern, and Postmodern Political Theory (1997).

'See, e.g., Pierre Schlag, Normative and Nowhere to Go, 43 Stan. L. Rev. 167 (1990) (criticizing modernist scholars for their normativity).

'See, e.g., Stephen M. Feldman, Please Don't Wish Me a Merry Christmas: A Critical History of the Separation of Church and State (1997) (presenting a critical social narrative of the separation of church and state).

10 I first heard the metaphor of the lawyer's toolbox from my professor in Contract Law, Jon Jacobson, who often referred to promissory estoppel as an essential tool in the contract lawyer's toolbox. Cf. Pierre Schlag, Normativity and the Politics of Form, 139 U. Pa. L. Rev. 801, 803, 860-61 (1991) (characterizing legal doctrine as a means, especially for trial lawyers, used to coerce others). 
learning to think like a lawyer." Recently, some broad-minded modernist scholars have sifted through the burgeoning production of postmodern scholarship and have recognized that certain postmodern insights might be useful for constructing modernist arguments.

In particular, these modernist scholars usually have seized upon one oft-discussed aspect of postmodern theory and have tossed it into their toolbox. Postmodernists from Stanley Fish to Jacques Derrida maintain that the traditions and culture of a community simultaneously enable and constrain all communication and understanding. ${ }^{12}$ Thus, for the individual within the community, one's current horizon of sociocultural prejudices and interests always shapes understanding, communication, and perception in general, including normative values and goals. ${ }^{13}$ This postmodern insight

"Philip Bobbitt has capitalized on this insight by using a Wittgensteinian pragmatic approach to specify six modalities or types of argument in constitutional law. See Philip Bobbitt, Constitutional Interpretation 11-22 (1991) [hereinafter Bobbitt, Constitutional Interpretation]; Philip Bobbitt, Constitutional Fate: Theory of the Constitution 3-8 (1982). Bobbitt writes that "the modalities of argument are no more than instrumental, rhetorical devices to be deployed in behalf of various political ideologies. The modalities of constitutional argument are the ways in which law statements in constitutional matters are assessed; standing alone they assert nothing about the world." Bobbitt, Constitutional Interpretation, supra, at 22.

${ }^{12}$ See, e.g., Jacques Derrida, Of Grammatology (Gayatri Chakravorty Spivak trans., Johns Hopkins Univ. Press 1974) (1967) (discussing deconstruction); Stanley Fish, Doing What Comes Naturally: Change, Rhetoric, and the Practice of Theory in Literary and Legal Studies (1989) (applying a postmodern approach to literary theory and interpretation); Hans-Georg Gadamer, Truth and Method (Joel Weinsheimer \& Donald G. Marshall trans., Continuum 2d rev. ed. 1989) (1960) (discussing philosophical hermeneutics).

${ }^{13}$ See Thiele, supra note 7 , at 83 (suggesting that the perspectivist denial of epistemological and ethical foundations is one of three main components of postmodernism; the social construction of identity and irony are the others); Feldman, The Politics, supra note 4, at 173-92 (discussing the postmodern approaches of Hans-George Gadamer and Jacques Derrida). Some modernists-particularly those who turned toward empiricism as a supposed source of objectivity-repudiated the idea that abstract logic could produce objective knowledge and at least implicitly questioned whether ethical values could be objective. And for those modernists, objectivity was the sine qua non of knowledge. Ethical values, for those modernists, seemed to arise from the unique personal and sociocultural circumstances of each individual. Nonetheless, such modernists-unlike postmodernists-inevitably believed in some foundational source of objective knowledge. Many thought that social science empiricism could somehow help identify the proper goals for instrumental reason and societal engineering. Postmodernists, on the other hand, are more thoroughgoing in their radical critique of objective knowledge. For postmodernists, we are always and already interpreting, and interpretation is always shaped by one's horizon of sociocultural 
can have radical implications: Derridean deconstructionists, for example, maintain that meaning is never grounded on a stable signified (an object that fixes meaning), but rather that there "is always already" a play of signifiers. ${ }^{14}$ Yet, despite its radical potential, modernists can appropriate this postmodern insight and use it as an instrument-a new doodad that can be wielded when constructing legal arguments. Indeed, some modernists have now put this postmodern insight into their lawyer's toolbox, storing it securely and taking it out only as needed. And for these modernists, this insight (or tool) can be most fruitfully exploited to criticize the normative positions of other modernists. But then, once the values and goals of others have been neatly deconstructed and swept away, the modernist writer typically begins to articulate his or her own normative position. Quickly, the tool must be returned to its box; otherwise, it might threaten the coherence of the writer's own express objectives.

Steven D. Smith is a modernist legal scholar who uses this postmodern tool. In his recent book on the separation of church and state, Foreordained Failure, ${ }^{15}$ he argues that the Constitution does not embody a principle of religious freedom. Of course, judges and constitutional scholars have long been asking "something like the following question: 'What is the meaning and scope of the principle of religious freedom embodied in the Constitution?"'16 If, as Smith maintains, no such principle exists, then this question becomes unanswerable.

Smith argues that many constitutional scholars use some type of theory to explicate a supposed principle of religious freedom in the First Amendment. ${ }^{17}$ To refute such theoretical approaches, Smith reaches into his toolbox and pulls out his postmodern doohickey. He contends that a general theory of religious freedom is impossi-

prejudices and interests. See Feldman, From Modernism, supra note 2, at 329-52 (discussing the differences between modernist and postmodernist legal scholarship). An outstanding discussion of modernist legal scholarship is Edward A. Purcell, Jr., The Crisis of Democratic Theory: Scientific Naturalism \& the Problem of Value (1973).

${ }^{14}$ Derrida, supra note 12 , at 73.

is Steven D. Smith, Foreordained Failure: The Quest for a Constitutional Principle of Religious Freedom (1995).

${ }^{16} \mathrm{ld}$. at 6.

${ }^{17}$ See id. at 6-7. 
ble: Any such theory inevitably founders on a logical conundrum. ${ }^{18}$ Thus, according to Smith,

[t] he function of a theory of religious freedom is to mediate among a variety of competing religious and secular positions and interests, or to explain how government ought to deal with these competing positions and interests. To perform that function, however, the theory will tacitly but inevitably privilege, or prefer in advance, one of those positions while rejecting or discounting others. But a theory that privileges one of the competing positions and rejects others a priori is not truly a theory of religious freedom at all-or, at least, it is not the sort of theory that modern proponents of religious freedom have sought to develop."

In other words, Smith here draws upon the postmodern assertion that all normative values or positions are culturally and socially contingent. To postmodernists, all theory-indeed, all communication and understanding-arises from one's current horizon of sociocultural prejudices and interests. ${ }^{20}$ Likewise, Smith readily argues that any theory of religious freedom-as a distinctive normative position-necessarily rests upon certain (often tacit) background beliefs or assumptions. Those background beliefs or assumptions always remain controversial and are exactly the types of assertions that the theory itself supposedly reconciles neutrally with other competing beliefs. But, of course, the theory cannot neutrally reconcile its own assumptions with other competing beliefs exactly because the theory rests on those very assumptions. Smith concludes, "The problem, simply put, is that theories of religious freedom seek to reconcile or to mediate among competing religious and secular positions within a society, but those competing positions disagree about the very background beliefs on which a theory of religious freedom must rest." ${ }^{21}$

At this point, though, Smith tosses his postmodern gizmo back into the toolbox. He wants to critique the jurisprudence of the re-

"See id. at 55-117.

${ }^{3}$ Id. at 63.

" See Gadamer, supra note 12, at 282-85, 302-03; FeIdman, The Politics, supra note 4, at 174-75, 185-87; Feldman, The Persistence of Power, supra note 4, at 2258-66.

"Smith, supra note 15 , at 68 . Smith adds that "the dependency of theories of religious freedom on background premises or beliefs poses an insuperable obstacle to the development of any theory of religious freedom of the kind that modern scholars have aspired to supply." Id. at 64. 
ligion clauses but not to become embroiled in larger jurisprudential controversies regarding theory: "I do not want to deny in any universal way that 'theory' may be possible and desirable in the law; my challenge here is directed only to theories of religious freedom."22 Smith's reluctance to follow the extended implications of his postmodern insight enables him to conclude with a normative recommendation for the Supreme Court. Although he qualifies this recommendation, he nonetheless suggests that the Court should consider refusing to enforce a principle of religious freedom, leaving the protection of religious liberty and equality to the "political process. ${ }^{.23}$ Hence, Smith manages to sidestep the potentially radical political implications that postmodernism might imply for constitutional jurisprudence in general and instead reaches a politically conservative conclusion. ${ }^{24}$

Cass Sunstein, perhaps more so than any other modernist writer, masterfully uses the postmodern insight into the contingency of normative values and goals. As a general principle, according to Sunstein, many constitutional provisions require that governmental actions be neutral. ${ }^{25}$ The problem, then, is to identify how neutrality

22 Id. at 61.

${ }^{23}$ Id. at 126. Smith writes:

So it is not as unthinkable for me as it may be for some legal scholars that the courts perhaps should simply withdraw from the business of trying to define and protect religious freedom. But to say that this possibility deserves serious, respectful consideration, as the final chapter suggests, is not to advocate such a course; and in fact I do not mean surreptitiously to advocate judicial withdrawal, as some reviewers seem to have believed. I mean no more than the final chapter says-that the possibility should not be regarded as beyond serious consideration.

Id. at viii.

${ }^{24}$ See Feldman, The Politics, supra note 4, at 183-84, 199-201 (focusing on the potentially radical political implications of postmodernism); see also Stephen M. Feldman, Principle, History, and Power: The Limits of the First Amendment Religion Clauses, 81 Iowa L. Rev. 833 (1996) (focusing on the importance of Smith's conclusions in the specific context of religion clause jurisprudence).

${ }^{2}$ See Cass R. Sunstein, The Partial Constitution 2-4 (1993) [hereinafter Sunstein, Partial]. This book by Sunstein drew heavily upon many articles that he had written during the previous decade. See Cass R. Sunstein, Neutrality in Constitutional Law (with Special Reference to Pornography, Abortion, and Surrogacy), 92 Colum. L. Rev. 1 (1992); Cass R. Sunstein, Preferences and Politics, 20 Phil. \& Pub. Aff. 3 (1991); Cass R. Sunstein, Lochner's Legacy, 87 Colum. L. Rev. 873 (1987) [hereinafter Sunstein, Lochner]; Cass R. Sunstein, Legal Interference with Private Preferences, 53 U. Chi. L. Rev. 1129 (1986) [hereinafter Sunstein, Legal Interference]; Cass R. Sun- 
can be determined. Neutrality can be measured only if one has some starting point, some baseline from which to calculate. Sunstein persuasively argues that many other scholars, as well as Supreme Court Justices, have assumed that the current status quo provides the appropriate baseline for decision. ${ }^{26} \mathrm{He}$ explains that others commonly have defined "neutrality by taking, as a given and as the baseline for decision, the status quo, or what various people and groups now have: existing distributions of property, income, legal entitlements, wealth, so-called natural assets, and preferences." ${ }^{27}$ The status quo, in this sense, is deemed natural and just. Hence, a governmental action that respects the status quo appears to be neutral, while one that disturbs the status quo seems partisan and thus constitutionally suspect..$^{25}$ In fact, as Sunstein recognizes, this form of reasoning is often used to determine whether the government has acted at all. If a governmental decision leaves the status quo intact, then the decision is "perceived to stay close to nature and thus to amount to no action at all.".29 And of course, in most instances, if the government is deemed not to have acted, then there can be no constitutional violation.

At this point in his argument, Sunstein reaches into his lawyer's toolbox and pulls out that most remarkable doohickey: the postmodern insight that all values and goals are socially and culturally contingent. With this tool in hand, Sunstein readily demonstratestime after time- that various positions which take the status quo as a baseline are mistaken exactly because all baselines are always contingent. ${ }^{30}$ For example, during the Lochner era of the early

stein, Interest Groups in American Public Law, 38 Stan. L. Rev. 29 (1985); Cass R. Sunstein, Naked Preferences and the Constitution, 84 Colum. L. Rev. 1689 (1984).

${ }^{2 \times}$ See Sunstein, Partial, supra note 25 , at 1-4.

${ }^{27}$ Id. at 3.

${ }^{2 x}$ See id. at 3-4, 348 .

2 Id. at 3.

${ }^{39}$ As Sunstein writes, "Status quo neutrality disregards the fact that existing rights, and hence the status quo, are in an important sense a product of law." Id. at 4.

It is worth noting that Sunstein occasionally claims that his approach is not novel but rather follows New Deal and American legal realist arguments. See id. at 6-7. The realists were among those modernists who repudiated the idea that abstract logic could produce objective knowledge and at least implicitly questioned whether ethical values could be objective. See supra note 13 and sources cited therein. Nevertheless, Sunstein's argument seems, at points, to go beyond the realist critique (such as in his discussion of constitutional interpretation in general). In fact, he explicitly acknowledges that the "views presented here will depart in important respects from those of 
twentieth century, the Supreme Court assumed that the common law "was prepolitical and natural." 31 The common law of property and contract rights was therefore deemed to be the proper baseline from which to judge the constitutionality of governmental actions. This view led (or allowed) the Court to strike down many legislative actions that had been intended to improve the general welfare of a large segment of American society, such as a federal statute that restricted the use of child labor, ${ }^{32}$ because such enactments disturbed the status quo of property and contract rights. Sunstein applies his postmodern tool to this Lochner-era reasoning. ${ }^{33} \mathrm{He}$ argues that if all normative values and goals are shaped by sociocultural prejudices and interests, then all legal rights are socially and culturally produced. Certainly, then, the common law of property and contract is not part of nature but rather is produced by American culture and society-in particular, by an American legal culture that includes the governmental sanction of property and contract rights. Consequently, the Lochner-era reliance on the common law as a baseline for constitutional decision was unjustified and improper. ${ }^{34}$

Sunstein's use of postmodernism is most clear in his discussion of constitutional interpretation in general. Originalists such as Robert Bork argue that the requirement of neutrality demands that constitutional meaning be fixed by the intentions of either the framers or the ratifiers of the Constitution. ${ }^{35}$ Sunstein observes that

the realists." Sunstein, Partial, supra note 25, at 7. Moreover, as I will discuss in the text, Sunstein seems to recognize the radical postmodern potential of his position even as he withdraws from its implications. Thus, I agree with Ronald K.L. Collins's recent characterization of Sunstein as having "a deconstructive side." Ronald K.L. Collins, Outlaw Jurisprudence?, 76 Tex. L. Rev. 215, 236 (1997) (reviewing Deconstruction in a Nutshell: A Conversation with Jacques Derrida (John D. Caputo ed., 1997)).

${ }^{31}$ Sunstein, Partial, supra note 25, at 41; see, e.g., Lochner v. New York, 198 U.S. 45 (1905).

${ }^{32}$ See Hammer v. Dagenhart, 247 U.S. 251 (1918) (striking down law regulating child labor), overruled by United States v. Darby, 312 U.S. 100 (1941); cf. The Child Labor Tax Case, 259 U.S. 20 (1922) (striking down federal tax imposed on profits from factories that used child labor).

${ }^{33}$ In a sense, the term "postmodern tool" is oxymoronic. That is, the focus on the use of tools is more of a modernist concept than a postmodernist one. Nonetheless, this term seems more felicitous than the alternatives-something such as "postmodernlike tool."

${ }^{34}$ See Sunstein, Partial, supra note 25, at 45-67 (discussing cases from the Lochner era).

${ }^{35}$ See Robert H. Bork, The Tempting of America: The Political Seduction of the Law 3-5 (1990). 
"[t]his process, it is often thought, does not authorize interpreters to use their own values, commitments, or principles. Neutrality in interpretation consists precisely in the abandonment of the interpreter's own views." ${ }^{36}$ But, of course, any postmodernist would recognize that the originalist's ideal of neutrality is nonsensical. We are always and already interpreting: All textual understanding arises from one's horizon of sociocultural prejudices and interests. ${ }^{37}$ In Sunstein's words, "[t] tive meaning, or meaning without resort to interpretive principles." ${ }^{38}$ Interpretation is "inevitably situated" and never rests on "external foundations." ${ }^{\text {"39 }}$ Therefore, in the specific context of constitutional interpretation, the originalist's "conception of neutrality in interpretation is implausible [because it] is built on a conceptual mistake; it aspires to a form of neutrality that is literally impossible." ${ }^{40}$

As Sunstein himself recognizes, his postmodern doodad is an extraordinarily powerful instrument, but exactly because of its latent power, it is potentially dangerous. It can lead to an antifoundationalism that contravenes objectivity and modernist knowledge. In law, it can be turned against the idea of baselines in constitutional law, and more broadly, it threatens to disrupt the practice of modernist jurisprudence altogether. The postmodern insight into sociocultural contingency, according to Sunstein, "offers obscure guidance for constitutional courts; it counsels a general rejection both of neutrality and of baselines, but at least in some forms, it offers no alternative position from which to decide cases." ${ }^{\text {st }}$ Sunstein, though, does not wish to go down this path to postmodernism. He wants to retain the idea of "objectivity in law" and, through neo-

${ }^{35}$ Sunstein, Partial, supra note 25, at 7.

${ }^{37}$ See Feldman, The Politics, supra note 4, at 173-92 (focusing on postmodern views of interpretation); cf. Feldman, Diagnosing Power, supra note 4, at 1059-74 (illustrating how a postmodern approach can deconstruct a legal rule). Francis J. Mootz writes, "If a core theoretical premise of contemporary hermeneutics exists, it is the universality of the hermeneutical situation." Francis J. Mootz. III, The New Legal Hermeneutics, 47 Vand. L. Rev. 115, 126 (1994) (book review).

3. Sunstein, Partial, supra note 25 , at 8.

${ }^{3 *}$ Id. at 115.

${ }^{49}$ Id. at 8 . Sunstein concludes, "The meaning of any text, including the Constitution, is inevitably and always a function of interpretive principles, and these are inevitably and always a product of substantive commitments." Id.

${ }^{41}$ Sunstein, Lochner, supra note 25, at 905. 
pragmatic arguments, to advocate explicitly for certain normative positions. ${ }^{42}$ Consequently, once he has used his postmodern tool to deconstruct the positions of other modernist writers, he must quickly return it to his toolbox.

Sunstein's belief that the postmodern notion of sociocultural contingency can be used only when desired and can be, at other times, tucked safely away emerges most clearly in his discussion of the concept of "naked preferences." ${ }^{43} \mathrm{He}$ argues that the judicial role is to assure that legislative acts result from the articulation and pursuit of public values rather than from the exercise of naked preferences or, in other words, "raw political power." 44 Public values arise from political deliberation, while naked preferences are exogenous to social and political influences and are chosen autonomously by individuals. Naked preferences, in short, are "preexisting private interests." 45 As such, naked preferences provide, according to Sunstein, neutral and objective Archimedean points for judicial decisionmaking. ${ }^{46}$ Courts supposedly can recognize naked preferences, and if a court concludes that a legislative act arose from a naked preference, then the act should be held unconstitutional. ${ }^{47}$

Quite clearly, Sunstein's concept of naked preferences contravenes the postmodern emphasis on the sociocultural contingency of normative goals and values. To a postmodernist, an individual cannot possibly choose a preference outside the context of social structures and cultural commitments. Sunstein himself, at times, appears to recognize the tenuousness of his concept of naked preferences. Indeed, he occasionally seems to dwell on the many social and political factors that can contribute to the "distortion" of

42 Sunstein, Partial, supra note 25 , at 8 . With regard to pragmatism, Sunstein asserts that John Dewey's "form of pragmatism has close links to the constitutional tradition I am describing." Id. at 141. Dewey focused on solving practical social problems, such as those related to education. See id.

${ }^{43}$ Id. at $25-37$.

4 Id. at $25,29$.

${ }^{45}$ Id. at 29.

${ }^{46}$ See id. at 25-39 (discussing how the ban on naked preferences provided ground for deciding numerous cases under different constitutional provisions); cf. Sunstein, Lochner, supra note 25, at 906 (arguing that there are "good reasons" for demanding "neutrality" in legislation).

${ }^{47}$ See Stephen M. Feldman, Exposing Sunstein's Naked Preferences, 1989 Duke L.J. $1335,1340-49$ (criticizing Sunstein's concept of naked preferences). 
"private" or naked preferences. ${ }^{48}$ While this line of reasoning might lead one to surmise that preexisting private interests or preferences, exogenous to social influences, do not truly exist, Sunstein resists this conclusion. Instead, he warns:

Lurking beneath the surface ... is a serious risk: the recognition that desires are social constructs, or are distorted by various factors, may tend to undermine the notion of autonony altogether. If the ideas of endogenous preferences and cognitive distortions are carried sufficiently far, it nay be inmpossible to describe a truly autononous preference. No desire is unaffected by social forces. If the notion of autonomy is abandoned, the realm of permissible legal interferences may become linitless-hardly a comforting prospect. ${ }^{49}$

Thus, to retain the idea of individual autonomy, to retain the idea of objectivity, and to Sunstein's mind, to retain the very idea of legitimate constitutional decisionmaking, he must limit the use of his postmodern tool. It can be used periodically, but we must carefully protect against its apparent potential for chaotic disruption. ${ }^{50}$

In general, the domestication of a postmodern insight for the purpose of constructing a modernist argument can seriously skew a writer's conclusions, as revealed by the earlier discussions of Smith and Sunstein. Smith applied his postmodern doohickey and found

*: Sunstein, Legal Interference, supra note 25 , at 1136, 1139-40.

${ }^{4}$ Id. at 1170 (footnote omitted).

s) From my perspective, Sunstein appears to misunderstand postmodern interpretive theory. He suggests that postmodernists are, in his language, either conventionalists or deconstructionists. In other words, according to Sunstein's understanding of postmodernists, they believe either that meaning is merely imposed by persons in positions of authority or that meaning is radically indeterminate. See Sunstein, Partial, supra note 25, at 114-15. I offer a more nuanced approach to postmodern interpretivism in Feldman, The Politics, supra note 4, at 173-201. Nonetheless, I do agree with Sunstein on some points (though I usually would choose different words to express the ideas), particularly when he hints at a more sophisticated postmodern view. For example, he writes:

It is right to say that there is no external perspective, that interpretive principles are inevitable, and that legal meaning cannot be grounded without language or culture. But this does not mean that all argument is manipulation or that good reasons cannot be offered on behalf of one view rather than another.... This choice-between transcendental foundations on the one hand and chaos or arbitrariness on the other-is unnecessary ....

Sunstein, Partial, supra note 25, at 115-16. Regardless, I clearly depart from Sunstein's position when he insists that objectivity and naked preferences exist. 
that a constitutional principle of religious liberty does not exist. If it were the case that other constitutional principles truly exist (which Smith seems to assume but does not address), then perhaps Smith's normative suggestion that the Court should consider not enforcing a principle of religious liberty might be sensible. After all, one might reasonably conclude that the Court can enforce only existent constitutional principles. Yet, if Smith's postmodern-like argument were expanded to suggest that no constitutional principles at all truly exist-at least not in the traditional sense-then Smith's normative suggestion becomes highly questionable. Religious liberty would be on no weaker footing than any other liberty or right. Thus, unlike Smith, one might suggest that the concept of constitutional principles needs to be completely rethought or that a coherent abstract constitutional principle is unnecessary to the pragmatic enforcement of general norms. Sunstein, meanwhile, uses his postmodern doodad to slash through the modernist positions of others but then refuses to thoroughly rethink constitutional jurisprudence from a postmodern perspective. Instead, he retreats to the comfortable Archimedean point of naked preferences and pronounces that there is indeed objectivity in law. In sum, the selective use of postmodernism as a critical tool-wielded against the views of other writers-still ostensibly allows the creative modernist author either to recommend a desired normative goal or to ground some preferred governmental process or normative value on a firm foundation.

\section{POSTMODERN DECONSTRUCTIONS}

\section{A. Schlag Deconstructs Langdell}

Pierre Schlag stands perhaps as the most unmitigated postmodernist and severest critic of modernist legal thought in the academy today. In a recent attack on modernist jurisprudence and, in particular, its progenitor, Langdellian legal science, Schlag imaginatively and provocatively analogizes legal thought to the nineteenth-century pseudo-science of phrenology. He begins by describing phrenology:

This discipline of phrenology was devoted to the identification of basic brain functions and their manifestations in cranial features. The basic principles and framework were established by Dr. Franz Joseph Gall. By sifting through an impressive ar- 
ray of empirical data, Gall sought to uncover the fundamental affective, moral, and intellectual faculties of human beings. ${ }^{51}$

For example, Gall accounted for behavior such as aggression by attributing it to a faculty for aggression. He attributed altruistic behavior to a faculty for benevolence, and so forth. ${ }^{\text {s2 }}$ How did Gall and the other phrenologists supposedly discover the specific fundamental faculties? Schlag explains that behaviors were "classified into descriptive categories. The descriptive categories [then were] hypostatized and projected back onto an agency, a potentiality, or a faculty whose defining character [was] its ostensible capacity to produce the behavior in question. The agency, potentiality, or faculty [was] then offered as an explanatory cause of the behavior." ${ }^{, 53}$

Gall and the other phrenologists enjoyed an extended period of enormous scientific prestige. ${ }^{54}$ Yet, ultimately, phrenology ended as a "grand failure" $\$$ largely because "Gall and the other phrenologists had their ontology wrong. The fundamental faculties (as such) did not exist." $\$ 6$ The phrenologists mistakenly had transformed descriptive classifications of behavior into ontological agenciesinto, that is, the fundamental faculties - that were then, in turn, deemed to be causes of the initial behavior. ${ }^{57}$ Moreover, because the faculties, in Schlag's words, "lacked any robust or stabilized referent, virtually anything could be said about how they were related to each other."ss Phrenologists therefore were able to construct complex analytical schemes that supposedly traced the interrelationships among the various faculties.

After critiquing phrenology, Schlag turns to the Langdellian jurisprudence that emerged during the later nineteenth century. Just as Gall was instrumental in the early stages of phrenology, Christopher Columbus Langdell was central to the development of modernist

\footnotetext{
${ }^{5}$ Schlag, supra note 6, at 878 (footnote omitted).

${ }_{52}$ See id. at 888 .

s3 Id.

$\$$ See id. at 877 .

ss Id. at 887.

sId. at 886 .

${ }^{57}$ See id. at 888 .

sx Id. at 889.

${ }^{39}$ See id. at 889-90.
} 
legal thought: "Both played a crucial part in establishing their respective disciplines as sciences." ${ }^{960}$ Schlag continues:

Phrenology and law both emerged as disciplinary knowledges through attempts to cast them in the form of sciences. Both "sciences" were aesthetically organized around a fundamental ontology of reifications and animisms- "faculties" in the case of phrenology, "doctrines" and "principles" in the case of law. Each discipline developed into an extremely intricate production of self-referential complexity. ${ }^{61}$

Thus, Langdell and his colleagues studied the decided cases in their efforts to discover legal principles and doctrines. They then organized these principles and doctrines into intricate and complex frameworks that supposedly maintained an internal logical consistency. Finally, they deemed these principles and doctrines to be, in effect, causal or controlling agencies, "at once generative of and constraining upon the official decisions of judges and other officials." ${ }^{26}$ In Langdellian legal science, Schlag observes, "doctrines and principles were doing some amazing things-and doing them, fully animated, all by themselves." ${ }^{63}$ Hence, for instance, Langdell said, "Equity will ... annex to such a contract an obligation directly to $B$," ' as if equity were an autonomous and self-motivated agent. ${ }^{64}$

The critical bite of Schlag's argument lies, of course, in his paralleling Langdellian legal science with the pseudo-science of phrenology. Just as the phrenologists failed to ground the fundamental

6 Id. at 896.

${ }^{61}$ Id. at 895-96.

${ }^{62}$ Id. at 902 . For prototypical illustrations of Langdellian legal thought, see Joseph Henry Beale, Jr., A Selection of Cases on the Conflict of Laws (2d ed. 1927); C.C. Langdell, Selection of Cases on the Law of Contracts (Boston, Little, Brown, and Co. 2d ed. 1879); William A. Keener, Methods of Legal Education (Part II), 1 Yale L.J. 143 (1892). For other extensive discussions of Langdellian legal science, see Neil Duxbury, Patterns of American Jurisprudence 10-25 (1995); William P. LaPiana, Logic and Experience: The Origin of Modern American Legal Education 22-28 (1994); Feldman, From Premodern, supra note 2, at 1426-38; Robert W. Gordon, The Case For (and Against) Harvard, 93 Mich. L. Rev. 1231, 1236-47 (1995) (reviewing LaPiana, supra); Thomas C. Grey, Langdell's Orthodoxy, 45 U. Pitt. L. Rev. 1 (1983); Marcia Speziale, Langdell's Concept of Law as Science: The Beginning of AntiFormalism in American Legal Theory, 5 Vt. L. Rev. 1 (1980).

${ }^{53}$ Schlag, supra note 6 , at 901.

${ }^{4}$ Id. (quoting C.C. Langdell, A Brief Survey of Equity Jurisdiction, 1 Harv. L. Rev. 55, 71 (1887), reprinted in C.C. Langdell, A Brief Survey of Equity Jurisdiction 17 (1905)). 
faculties on any stabilized referent, modernist legal scholars have failed to ground legal rules and principles on "any robust or stabilized referent." ${ }^{65}$ Langdellian legal scientists and their successors have written endlessly about legal doctrines as if the doctrines actually existed as "robust object-forms with stabilized identities." But when examined from Schlag's postmodern perspective, we see that nothing solid and stable is there. ${ }^{67}$

In another recent essay, Schlag elaborated on the ontological vacuousness of the law. ${ }^{69}$ Certain distinctive methods of legal education, according to Schlag, induce students to develop an abiding faith in the substantive existence of law. In particular, the abstruseness of Socratic questioning often leads law students to suspect that their professors are "hiding the ball"-where the ball metaphorically represents the law. ${ }^{69}$ Professors seem to move the ball around adeptly, flipping it from one hand to the other, sliding it behind the back, and always keeping it just out of the anxious sight of the (sometimes) attentive students. Watching this deft display, the students believe that the professors must be hiding the ball, since they never quite see it. Thus, the students implicitly assume that some ball actually exists: How could (and why would) professors perform such tricks if there were no ball? In this way, future attorneys develop "a pious faith in the ontological and epistemic character of law." They deeply believe in the ball, in a "stabilized preinterpretive" law." But of course, Schlag raises the postmodern

${ }^{\mathrm{KS}}$ Id. at 908.

«Id. at 900.

"See id. at 900-02.

Pierre Schlag, Hiding the Ball, 71 N.Y.U. L. Rev. 1681 (1996) [hereinafter Schlag, Hiding].

\%) Id. at 1684 .

"II Id.

"Id. at 1687. Schlag writes:

Sometimes the law teacher will insist that he is not hiding anything. He may insist that no one has ever given a good account of the ball or that indeed there is no ball at all. Sometimes, perhaps even often, he believes this. But it does not matter: he will not be believed. His epistemic skepticism (the ball is not knowable) and his ontological nihilism (there is no ball) are quite simply unbelievable to the law student: How could there be no ball-when everyone, the judges, the lawyers, the students, the professor himself are all always making references to the ball, invoking the ball, saying what the ball means, and doing things with it? How then could there be no ball? The idea is simply too preposterous to be entertained. 
deconstructionist point: Regardless of the faith or belief of attorneys and scholars, there just is no stabilized preinterpretive law. It does not exist.

In phrenology, the ontological emptiness of the so-called fundamental faculties allowed Gall and his followers to weave the faculties into intricate analytical frameworks. In a similar fashion, Langdellian legal scientists and other modernist scholars have devoted entire careers to the construction of increasingly elaborate doctrinal frameworks, neatly and logically relating the various principles and rules to each other. From Schlag's postmodern viewpoint, though, legal scholars can say just about anything they want about the principles and rules because-like the phrenological faculties-they do not actually exist (as stabilized referents). It is quite easy to construct a most imaginative and even elegant doctrinal edifice if one is working with that most pliant of materials-non-existent rules and principles. ${ }^{72}$

Ultimately, Schlag urges that just as we now recognize phrenology to have been a grand failure, we should recognize that Langdellian legal science and its successor forms of modernist legal scholarship are also failures, pseudo-sciences. Modernist legal scholars may believe that they know something-the doctrines and principles of the law-but they are as mistaken (or self-delusional) as the phrenologists once were. ${ }^{73}$ Schlag underscores the significance

The short of it is, as the student sees it, there must be a ball. And since there must be a ball, the problem can only be that the professor is hiding it.

Id. at 1684.

72 See Schlag, supra note 6, at 908.

${ }^{73}$ Schlag writes:

[T] he belief that legal thinkers know anything is on no more solid ground than the belief that phrenologists knew anything. Phrenologists, after all, also had a massive assemblage of bits of information. It has turned out, of course, that this knowledge was wrong. Although phrenology achieved a massive integration of many carefully arranged propositions, the phrenologists did not really know anything. What phrenologists knew was nothing more than what other phrenologists believed they knew, and what they knew was not knowledge.

Legal thinkers may well face the same predicament. What legal thinkers know is what other legal thinkers believe they know. Legal thinkers know how other legal thinkers will think about things-what kinds of arguments they are likely to make, what sources they will draw upon, what values and concerns they will invoke, and what conclusions they will offer. This knowledge is, in short, knowledge of the beliefs shared by particular kinds of persons-namely, persons who have undergone the same formal legal training.

Id. at 910-11 (footnote omitted). 
of his postmodern point by arguing that most current legal scholars still operate within the "Langdellian paradigm." Thus, the elaborate structures of legal rules and policy arguments that continue to fill law reviews and treatises are, at best, comforting myths. ${ }^{75}$ Schlag, though, seeks to dispel the myths-and any possible comfort-because "unlike phrenology, tremendous consequencesmandatory incarceration, forcible reallocation of wealth, even death-often turn upon 'the doing of law.",76

${ }^{74}$ Id. at 901-06; see also Pierre Schlag, Law as the Continuation of God by Other Means, 85 Cal. L. Rev. 427, 430-34 (1997) (discussing the treatment of legal doctrines as objects in their own right).

"Schlag also describes the phenomenon that I discuss in Part I of this Essay, the appropriation of postmodern insights by modernist scholars as they construct legal arguments. He notes how legal theorists have attempted to appropriate the ideas of writers such as Stanley Fish and Michel Foucault:

The efforts of legal thinkers to transform such improbable sources of knowledge into law are symptomatic of the continued hold of the Langdellian paradigm. These efforts are typical of what one does-what one is supposed to do-as a legal thinker. The task is to subsume, subordinate, and envelop new material, new contexts, and new problems within the Langdellian aesthetic. For elite legal thinkers, the task is basically to police law's empire, to guard its gates, to restate its timeless truths, and to deliver up new colonies.

Schlag, supra note 6 , at 906.

${ }^{76}$ Id. at 912 . Schlag expressly states that the claims of legal practice are, quite simply, unbelievable:

Those who understand themselves to be "doing law" must act as if they believe in the law, in its self-representations, and in its promises to effectuate its claimed ends. But, of course, to any person who is not busy "doing law," the claims of law often seem quite preposterous-simply not to be believed. Consider the kinds of things that American law asks judges, lawyers, law teachers, and law students to believe:

that law is open and generally known to the public;

that human action generally comports with Newtonian conceptions of causation;

that the legislative or bureaucratic actions of collective bodies, like legislatures, can be analyzed in terms of the human attribute of intention;

that there are determinative methods for deciding whether a case is "correctly decided";

that human states of mind comport with a schema that conveniently breaks down into the cognitive states known as "intent," "recklessness," and "negligence."

Then, too, we are asked to believe that there exists some technique or faculty that enables us to balance incommensurable goods (for example, the flag against the First Amendment) in order to reach correct outcomes. We are asked to believe that such balancing decisions are intersubjectively valid among a sufficiently 


\section{B. Deconstructing Schlag's Deconstruction of Langdell}

Schlag's critique of Langdellian legal science suggests that Langdell and his colleagues, like Gall and the phrenologists, made some incredible mistake. To Schlag, Langdellian legal science and, indeed, all of the modernist legal thought that succeeds it are largely "nonsense"- " almost entirely bereft of knowledge or insight." " And, it follows, if only Langdell had not been so "essentially stupid," to use Grant Gilmore's phrase ${ }^{78}$ American legal thought would have developed in some radically different-and better-direction.

Perhaps strangely, because I consider myself a postmodernist, this conclusion - this condemnation of Langdellian legal science and modernist legal scholarship in general-causes me to pause. To be sure, I do not wish to resurrect, justify, or celebrate Langdellianism. ${ }^{79}$ But I am interested in understanding how Langdell and his colleagues developed American jurisprudence and why the Langdellian paradigm has so strongly persisted in the academy. To suggest, as Schlag does, that Langdell was stupid and his legal science was nonsense, that his modernist successors have repeated for over a century the same gross errors, and that finally today a small group of elite (postmodern) professors can recognize this enormous mistake ${ }^{80}$ sounds just a bit too Whiggish for my (postmodern) sensibilities.

Ironically, Schlag seems to replicate the moves of current modernist scholars, such as Sunstein and Smith, who domesticate postmodernism by selectively using it as a critical tool in the construction of legal arguments. ${ }^{81}$ As discussed in Part I of this Essay, these modernist scholars sometimes skew their conclusions exactly because they have tried to domesticate postmodern insights. For a similar

large community (namely citizens) or a sufficiently enlightened community (namely the legal profession) that the decisions are legitimate.

Pierre Schlag, This Could Be Your Culture-Junk Speech in a Time of Decadence, 109 Harv. L. Rev. 1801, 1813-14 (1996) (reviewing Ronald K.L. Collins \& David M. Skover, The Death of Discourse (1996)).

$"$ Schlag, supra note 6, at 909-10.

${ }^{78}$ Grant Gilmore, The Ages of American Law 42 (1977).

${ }^{79} \mathrm{Cf}$. Colloquy, 20 L. \& Soc. Inquiry 691 (1995) (including essays that debate whether Langdell should be celebrated).

"For example, in Hiding the Ball, Schlag declares, "We are now in a position to begin to bring 'the ball' out of hiding." Schlag, Hiding, supra note 68, at 1687.

${ }_{81}$ Cf. Francis J. Mootz III, The Paranoid Style in Contemporary Legal Scholarship, 31 Hous. L. Rev. 873 (1994) (criticizing Schlag for suggesting that legal scholars can escape the maze of normative scholarship). 
reason, Schlag seems to have skewed his conclusion regarding Langdell and modernist scholarship. In other words, Schlag readily suggests that Langdellian legal scientists and their successors were grand failures exactly because Schlag focuses his deconstructive gaze too narrowly on Langdellian legal science.

Because Schlag is intent on deconstructing Langdellian legal science, ${ }^{s 2}$ he takes radical postmodern insights and uses them, in effect, as mere tools to critique Langdellianism. For example, Schlag criticizes the Langdellian legal scientists and their successors for mistakenly assuming that legal rules and principles have stabilized referents that firmly ground a preinterpretive meaning for the law. ${ }^{83}$ I agree completely with Schlag that no such stabilized referents exist in the law. But, as Schlag is certainly aware, this deconstructive critique is standard postmodernist fare; one could make (and postmodernists do it all the time) the same point about any text, not just legal texts. No principle, no concept, no text, in any field or discipline, has a stable referent that fixes or determines a preintrepretive meaning. ${ }^{84}$ Whether we are focusing on law or on anything else, we are always and already interpreting.

At another point, Schlag criticizes the Langdellians and their modernist successors for failing to recognize that there is "no specified method for distinguishing the doctrines, principles, or units of [legal] analysis that are authentic from those that are spurious." Again, I agree with Schlag. But again, it is important to recognize that this point is standard postmodernist fare. In Truth and Method, Hans-Georg Gadamer argued that no precise method or mechanical technique can lead to truth or to understanding in interpretation. ${ }^{86}$ Modernists might believe that the correct method will lead to an objective interpretation of a text, but postmodernists

:2 Schlag has deconstructed Langdellian legal science before. See, e.g., Pierre Schlag, The Problem of the Subject, 69 Tex. L. Rev. 1627 (1991) (deconstructing various modernist scholars).

"See supra Section II.A.

* See Feldman, The Politics, supra note 4, at 173-92 (discussing philosophical hermeneutics and deconstruction).

«s Schlag, supra note 6, at 907. Schlag continues, "To put it simply, in American law, there is no method because there is no specified core ontology, and there is no specified core ontology because there is no method." Id.

"See Gadamer, supra note 12, at xxi, 295, 309; see also Stephen M. Feldman, The New Metaphysics: The Interpretive Turn in Jurisprudence, 76 Iowa L. Rev. 661, 68283 (1991). 
contend otherwise. Hence, Schlag correctly observes that, in jurisprudence, no method can lead to objective meaning or truth, but the same is equally true in history, economics, psychology, or any other discipline.

So what? Should Schlag be faulted for focusing on jurisprudence instead of examining all disciplines or modernist thought in general? Well, yes and no. On the one hand, Schlag is a law professor writing for a law journal, so his concentration on jurisprudence is understandable. Furthermore, his critique of Langdellian legal science is provocative and full of insights. On the other hand, his narrow spotlight on jurisprudence tends to skew his conclusions. For instance, if it were the case that only jurisprudence lacked stabilized referents while other disciplines actually had them, then one might suggest, as Schlag does, that Langdell was stupid and that his jurisprudence and its later modernist derivations were nonsense. From this perspective, Langdellians and other modernist legal scholars appear to be making a huge mistake that is not replicated in most other disciplines (excepting phrenology). Yet, if it were instead the case that jurisprudence lacked stabilized referents and all other disciplines also lacked stabilized referents, then one might reach a very different conclusion. One might instead suggest that all modernist disciplines need to be rethought from a postmodern perspective, or one might suggest that modernist elements in academic disciplines are intractable, or a host of other possibilities. ${ }^{87}$

Most important, from this latter perspective, jurisprudence does not look so unique. Certainly, law is different in important ways from other disciplines, but it is also similar in important ways. And those aspects of modernist jurisprudence that Schlag most often deconstructs, such as the lack of stabilized referents, typically are shared with other disciplines. This recognition suggests that maybe Langdell was not so stupid after all. Perhaps Langdell and his colleagues merely were doing what modernist academicians, in other fields, were doing at that time.

\footnotetext{
${ }^{87}$ For example, another distinct possibility is to consider whether the concept of having separate disciplines is an outmoded modernist vestige. See Douglas Kellner, Postmodernism as Social Theory: Some Challenges and Problems, 5 Theory Culture \& Soc'y 239, 241 (1988) (suggesting that postmodernists tend to subvert the boundaries among different academic disciplines).
} 
In fact, jurisprudence can be compared more fruitfully to the social or human sciences such as history and sociology than to phrenology. In 1870, when Langdell first became dean of the Harvard Law School, American universities were just entering an important transitional period; they were reforming and ascending as major institutions within American society. ${ }^{\$ S}$ Moreover, at that time, the faculty and leaders of these new universities confronted a rapidly changing intellectual landscape. ${ }^{89}$ In particular, American academicians faced two interrelated developments: "the collapse of older theologies," and the emergence of a new "historicist sensibility." The collapse of older theologies meant that secularization was advancing; intellectuals could no longer readily attribute natural and social events to God's will. The new historicist sensibility reflected

Key resources for understanding the emergence of the new universities and the changes in American intellectual thought during the postbellum period include George M. Marsden, The Soul of the American University: From Protestant Establishment to Established Nonbelief (1994); Peter Novick, That Noble Dream: The "Objectivity Question" and the American Historical Profession (1988); Dorothy Ross, The Origins of American Social Science (1991); Laurence R. Veysey, The Emergence of the American University (1965).

s) Laurence R. Veysey distinguishes the old colleges of the pre-Civil War era from the new universities of the postbellum period. See Veysey, supra note 88, at 1-18.

"Marsden, supra note 88, at 187. Dorothy Ross suggests that American intellectuals of the postbellum period did not reject religion, but rather they shifted the terms of the relationship between science and religion:

The gentry intellectuals who attacked religious control did not want to destroy the harmony between religion and science but to recast it. Positivist science was to set the terms of the agreement rather than orthodox religion. Few of them actually became agnostics; most adjusted the basis of their Christian faith to avoid cognitive conflict with natural science. For all of them, however, the influence of positivism forced for the first time in America a divorce between natural knowledge and revealed Christianity and a determination to develop natural knowledge on its own terms.

Ross, supra note 88 , at 57.

" G. Edward White, The Marshall Court and Cultural Change, 1815-35, at 6 (1988). White discusses the lack of a historicist sensibility in America during the Marshall Court years. See id. at 6-7. He defines historicism as "a stance which assumes that qualitative change is a given in the course of nations." Id. at 374 . Ross suggests that "[t]he development of historicist thinking in the nineteenth century is important because a shift in historical consciousness may well be the underlying ground for the major intellectual changes that occurred in American social thought between the 1880s and 1920." Dorothy Ross, The Liberal Tradition Revisited and the Republican Tradition Addressed, in New Directions in American Intellectual History 116, 125 (John Higham \& Paul K. Conkin eds., 1979). 
an increasing awareness that, because of human willpower and creativity, the world could continually change and, in fact, improve. ${ }^{92}$ American intellectuals reacted anxiously to these developments by seeking objectivity and control. ${ }^{93}$ Most academicians in the human sciences were no longer comfortable grounding knowledge on God, but this secularization did not diminish their desire for objectivity. Fearful of, and thus unwilling to accept, a world of radical subjectivity, relativism, and arbitrariness, they embarked on a modernist quest for some new source (or sources) of objectivity. This quest for objectivity provided the broad agenda for modernist research, a primary mission of the burgeoning universities. ${ }^{94}$ If God

${ }^{2}$ See Zygmunt Bauman, Modernity and the Holocaust 91-92, 113-14 (1989); Ross, supra note 88 , at 4,58 ; White, supra note 91 , at $6-7,374$. Ross explicitly ties the advance of secularization with the emergence of a historicist attitude, which she sees as first emerging in Europe in the early nineteenth century and then in America in the latter part of the century. Ross writes about Europe of the early nineteenth century:

The modern understanding of history was one aspect of the broader movement toward secularization. The Christian view that eternal time was punctuated by an ascending sequence of sacred events was projected into secular time, imparting a degree of meaning and progressive organization to history. At the same time, the changing earthly world was slowly loosed from the eternal world of God and His immutable truth, and secular modes of understanding the particular configurations of human history gained authority. Change could then be understood as a succession of qualitatively different phenomena, not merely as random variations, or the surface appearance of essentially unchanging things, or the recurring cycle of an endless wheel. The past became both qualitatively different from and causally linked to the present. It was not until the early nineteenth century that this understanding of history as a continuous procession of qualitative changes came fully into view and that many European thinkers began to interpret the whole of reality, including what had earlier been conceived as absolute and unchanging, in contextual historical terms. I will call this new view of history "historicist" and this new interpretive tendency "historicism."

Ross, supra note 88, at 4. Regarding the postbellum period in America, Ross adds, "For the first time Americans were forced into an awareness of historicism as a premise of their own world." Id. at 58. For a discussion of why American intellectuals trailed Europeans in coming to a historicist sensibility, see id. at 22-26.

${ }^{93}$ According to Ross, these developments "heightened traditional anxieties and intensified the desire for control." Ross, supra note 88, at 318. Most "social scientists sought permanence and value by reconstructing transitory historical experience into natural process and by exerting rational control." Id.

${ }^{24}$ See Veysey, supra note 88, at 12 (asserting that research, service, and culture were the three primary goals of the new universities); Feldman, From Modernism, supra note 2, at 325-29 (explaining modernism as, in part, a quest for objectivity). George M. Marsden argues that intellectuals sought to fill "the void left by the collapse of older theologies." Marsden, supra note 88, at 187. Ross adds, "So far as pos- 
was dead (at least for epistemological purposes), then a Godsubstitute had to be found. ${ }^{95}$ Even in the discipline of history, which would seem most likely to accept the possibility of radical historical contingency, the ideal of objectivity became "the central norm of the profession." ${ }^{.96}$ Initially, many academic disciplines, claiming the authoritativeness of a science, sought objectivity in some type of formalism, a focus on axiomatic principles and logically coherent systems. ${ }^{97}$ According to George M. Marsden, postbellum academicians displayed a "passion for order, systematizing, efficiency, scientific principle, [and] personal discipline."'s

Quite clearly, Langdellian legal science fit neatly within the latenineteenth-century university. And one should not have expected otherwise. The president of Harvard, Charles Eliot, was at the forefront of the movement to create the new type of university, and he personally chose Langdell to run the law school." ${ }^{99}$ ike other

sible, change was contained and history rendered harmless." Ross, supra note 88 , at 61. Veysey writes:

[T] he researcher had to believe that he was making contact with "reality" itself-in other words, that gold as well as dross existed in the universe and that his special training made him capable of knowing the difference. The gold of reality lay in particular phenomena which could be isolated and then systematically investigated....

Veysey, supra note 88, at 135 (footnote omitted).

"See Friedrich Nietzsche, The Gay Science (1882), reprinted in The Portable Nietzsche 95 (Walter Kaufmann trans. \& ed., Penguin Books 1954) (asserting that "God is dead").

"Novick, supra note 88 , at 16 (arguing that objectivity became established as the central norm in history during the 1880s). Dorothy Ross concurs, "Like the social sciences, academic history has not accepted a fully historicized view of itself and hence not fully recognized its dialogic relation to the past." Ross, supra note 88, at 474 .

"See Feldman, From Modernism, supra note 2, at 329-31 (describing this first stage of American legal modernism); cf. Morton G. White, Social Thought in America: The Revolt Against Formalism 11 (1949) (focusing on the rejection of formalism in the early twentieth century). On the significance of scientific authoritativeness, Peter Novick observes, "Science ('objective science,' the 'scientific fact') was never more highly regarded in the United States, was never more of a cult, than in the late nineteenth and early twentieth centuries." Novick, supra note 88 , at 31 ; see also Ross, supra note 88, at 62 (emphasizing the importance of scientific authority). Novick adds, "No group was more prone to scientific imagery, and the assumption of the mantle of science, than the historians." Novick, supra note 88 , at 33 .

Marsden, supra note 88, at 187.

"See LaPiana, supra note 62, at 7-28 (discussing the relationship between Eliot and Langdell); Marsden, supra note 88, at 186-89 (focusing on Eliot). According to Marcia Speziale, although Eliot chose Langdell, the faculty still had to vote Langdell in as dean. See Speziale, supra note 62, at 10-11. 
disciplines, jurisprudence sought to confront the collapse of an old theology. Specifically, in law, the old theology was natural law, and the new outlook was positivism; the Civil War marked a watershed in the transition from a natural law to a positivistic orientation. ${ }^{100}$ Langdell and his colleagues were the first American jurisprudents who needed to understand and legitimate the common law system in a now-positivist world. And the Langdellians confronted this challenge with the tools, methods, and claims that typified the period: They wore the mantle of scientific authority, they sought objective knowledge of reality, and they logically systematized their findings. Hence, when Langdell argued that the law professor should be a legal scientist focused on research and not an attorney experienced in practice, when he stressed the need to sift through thousands of cases to find the "exceedingly small proportion" that are "useful and necessary" for the study of law, and when he emphasized that there were but a few axiomatic principles of law that could be logically systematized, ${ }^{101}$ Langdell did no more than duplicate the claims and actions of similarly-situated academicians in other disciplines. ${ }^{102}$

\section{CONCLUSION: PICKING UP THE PIECES}

Langdellian jurisprudence does not seem at all odd when it is understood within the contemporary history of the human sciences in America. Moreover, Langdell's modernist successors in juris-

${ }^{100}$ See Feldman, From Premodern, supra note 2, at 1417-26 (discussing the factors contributing to the transition from natural law to positivism). Ross writes, "The gentry intellectuals of the 1870 s presided over a watershed in the development of the social science disciplines in America. The Civil War and rapid industrialization-very much like the French Revolution and industrialization earlier in France and England-introduced a new turn toward positivism, historicism, and class consciousness."

Ross, supra note 88 , at 63-64.

${ }^{101}$ Langdell, supra note 62 , at viii.

${ }^{102}$ The similar viewpoints of many intellectuals in the various academic disciplines also manifested a class crisis among old stock Protestants in America. Some members of this gentry class were called "mugwumps" during the Gilded Age because of their "efforts to replace corrupt politicians with the disinterested leadership of the 'best men,' namely themselves. Faced with the specter of class conflict, they both feared for their established position and welcomed their opportunity for leadership." Ross, supra note 88 , at 61 . When the more intellectual mugwumps found state and national governments to be less amenable than the colleges to their claims of authority, they led the emergence of the new universities. See id. at 62-63. Thomas C. Grey places the Langdellians within this mugwump class. See Grey, supra note 62, at 35. 
prudence, who continued to seek objectivity (though in other ways), generally fit just as closely with their contemporaries. As Peter Novick says of the history profession, the ideal of objectivity sometimes has been questioned, attacked, and modified, but it still remains "remarkably enduring." 103 Pierre Schlag's misleading characterization of Langdellian legal science and its modernist progeny as "nonsense" that is "almost entirely bereft of knowledge or insight" flows from his overly narrow focus-from his failure to examine Langdellian jurisprudence in its own context. ${ }^{104}$ Once understood in a broader context, the modernist adherents of the Langdellian paradigm do not seem quite so stupid (unless everyone in all academic disciplines was similarly stupid for at least a century, and again, this view seems a bit too Whiggish).

Ironically, just as I criticize Schlag for focusing too narrowly on Langdellian jurisprudence, he similarly criticizes modernist legal thinkers for "indulging an instinct for the small scale."105 These modernists misleadingly ignore their context and implicitly assume certain answers to "large-scale questions" that remain hidden in the background. ${ }^{106}$ Ultimately, Schlag declares, this narrow focus skews the modernists' conclusions: "[T]he value of any conclusion they draw depends upon the strength of the large-scale answers that they unwittingly provide to questions they have not asked."107

The recognition that both Schlag and I make similar critical moves suggests the conventionality of this very move within postmodern theory. All writers, including postmodernists as well as modernists, express a position or point of view. The point of view of modernist writers may be more obvious since they often expressly

\footnotetext{
${ }^{163}$ Novick, supra note 88 , at 2 . Novick breaks the development of the history profession in America into four stages, which closely resemble the four stages in my heuristic breakdown of American legal modernism. See Feldman, From Modernism, supra note 2, at 329-44 (tracing four stages of American legal modernism).

${ }_{104}$ Schlag, supra note 6, at 909-10. It is worth mentioning that Schlag makes another mistake because of his lack of historical context. He asserts that Langdell was instrumental in establishing jurisprudence as a science, see id. at 896, but jurisprudence had been referred to as a science long before Langdell. See Joseph Story, Course of Legal Study (1817), reprinted in The Miscellaneous Writings of Joseph Story 66, 6971, 73, 79 (William W. Story ed., Da Capo Press 1972) (1852); Feldman, From Premodern, supra note 2 , at $1396,1400-17$.

165 Schlag, supra note 6, at 910.

lix Id.

${ }^{1 / 2}$ Id.
} 
recommend a normative goal or value, but postmodernists too try to communicate some idea or critical theme that necessarily arises from a distinctive position or point of view. Even the most steadfast postmodernist who successfully conveys an unmodern sense of openness or tentativeness-for example, by explicitly narrating instead of arguing, or by interpreting instead of describing-always has at least an implicit position or point of view. ${ }^{108}$ And from a postmodern perspective, any position or point of view necessarily rests on certain background assumptions-a background context. Hence, one sure-fire way to critique another writer, whether modermist or postmodernist, is simply to point out how that writer has certain unexamined background assumptions. ${ }^{109}$ Of course, from a postmodern standpoint, having unexamined background assumptions is unavoidable, but nonetheless, this recognition does not in any way help fortify those assumptions. Thus, the postmodernist can always bring somebody else's background assumptions to the forefront and subject them to critique. Any text, even a postmodern deconstructive text, can be deconstructed. ${ }^{10}$

In a sense, then, I can even deconstruct my own Essay. Just as I assert that Schlag focuses too narrowly on Langdellian legal science when his deconstructive points apply across a much larger field (to modernist scholarship in general), I can now argue that I also focus too narrowly. I unduly stress Schlag and his essay on law

${ }^{108} \mathrm{Cf}$. Bauman, supra note 7, at 21-22 (arguing that one of the best ways to understand the movement from modernity to postmodernity is in the transition of the role of intellectuals from legislators to interpreters).

108 See Martha Minow \& Elizabeth V. Spelman, In Context, 63 S. Cal. L. Rev. 1597, 1609-12 (1990) (emphasizing how a focus on context can be used to critique the positions of others).

${ }^{110}$ According to Derrida, postmodernists cannot escape the modernist metaphysics of presence. He writes that "deconstruction always in a certain way falls prey to its own work." Derrida, supra note 12 , at 24 . He adds that "we can pronounce not a single destructive proposition which has not already had to slip into the form, the logic, and the implicit postulations of precisely what it seeks to contest." Jacques Derrida, Structure, Sign, and Play in the Discourse of the Human Sciences, in Writing and Difference 278, 280-81 (Alan Bass trans., University of Chicago Press 1978). Rita Felski expresses the inescapability of the modernist metaphysics of presence in different terms, specifically related to her feminist viewpoint: "I have contended that to write about modernity is always to be implicated, whether unwittingly or selfconsciously, in hierarchies of sexual difference." Rita Felski, The Gender of Modernity 208 (1995). I have written elsewhere that postmodernism always includes "vestiges of the modern." Feldman, Diagnosing Power, supra note 4, at 1083. 
and phrenology when my deconstructive points actually apply across a much larger field (to postmodernist scholarship in general). Put in different words, I express a particular point of view in this Essay because, in part, I am writing about Schlag and not about something else, and in doing such writing, I accept (at least temporarily) certain background assumptions. Those background assumptions, of course, could be brought to the foreground and critiqued (but, of course, other background assumptions would then stand behind the critique, and so on, ad infinitum). Regardless of how postmodern a writer seeks to be, if she writes an essay or, for that matter, communicates in any manner at all, then she must somehow domesticate postmodernism. If one doggedly tried to follow postmodern insights to their furthest reaches, then everything would be deconstructed, including those postmodern insights; imagine traveling continually outward until being caught suddenly in the gravitational field of an interstellar black hole that was sucking everything, including yourself, into its abyss. So, to avoid such a deconstructive implosion, we always at some point manage to stop: to talk, to communicate, to write, to whatever."'

For this reason, Schlag could not avoid domesticating postmodernism in some manner. If he writes anything, he must at some point stop the deconstruction. And since he must do so, someone else-like me-can always come along and deconstruct Schlag's essay. Even the most unmitigated postmodernist ultimately uses some postmodern insights as if they were tools or instruments-to express a point of view. ${ }^{112}$ Hence, the use of postmodern insights in

\footnotetext{
"' See J.M. Balkin, Tradition, Betrayal, and the Politics of Deconstruction, 11 Cardozo L. Rev. 1613, 1627 (1990) (arguing that although deconstruction could go on forever, "we always do stop"). Indeed, all understanding and communication have both a constructive and deconstructive side. See Feldman, The Politics, supra note 4, at 185-92 (discussing the relation between philosophical hermeneutics and deconstruction). Any hermeneutic act simultaneously produces meaning and destroys meaning. It simultaneously privileges certain assumptions and denies or denigrates other possible assumptions. For this reason, Gadamer can emphasize that tradition enables us to open up the meaning of a text, while Derrida can warn us that the authority of tradition is "purchased by deep violence." John D. Caputo, Gadamer's Closet Essentialism: A Derridian Critique, in Dialogue and Deconstruction: The Gadamer-Derrida Encounter 258, 263 (Diane P. Michelfelder \& Richard E. Palmer eds., 1989).

112 Thus, I have argued elsewhere that the postmodern scholar can always become "the postmodern police, scanning the scholarly production of other postmodernists for the inevitable traces of modernism." Feldman, Diagnosing Power, supra note 4,
} 
such an instrumental manner does not necessarily render a writer's position or point of view prosaic. In fact, for what it's worth, although I have criticized Sunstein and Smith as modernist writers who domesticate postmodern insights, I usually find their work more interesting than that of other modernist writers who seem to have no grasp of postmodernism at all. And I typically find the work of a thorough-going postmodernist such as Schlag even more interesting and provocative. Most important, the work of postmodern deconstruction does not become trite merely because any text can be deconstructed. To the contrary, if there are postmodern paths to justice, they lie in the deconstructive disclosure of the ever-present tacit assumptions and cultural values that always hide or marginalize some metaphorical Other-an oppressed and subjugated subcultural group. ${ }^{1 / 3}$

Finally, if postmodernist as well as modernist writers inevitably domesticate postmodern insights, then what differentiates them from each other (besides the fact that modernists overtly articulate and defend normative values and goals)? In part, the difference lies in their attitudes. ${ }^{114}$ The modernist writer uses postmodern insights, like any other tool in the toolbox, with anxiety. Anxiety arises because the modernist uses her tools earnestly in the pursuit of objectivity even as she constantly doubts the efficacy of those tools-even doubts the possibility of objectivity. Consequently, we find a writer as sophisticated as Sunstein anxiously brooding that if his postmodern doohickey fell into the wrong hands, it might leave no legitimate "position from which to decide cases." 115 The postmodern

at 1096. In this vein, I have criticized Jack Balkin for becoming overly modernist in the midst of his postmodernism. Compare J.M. Balkin, Transcendental Deconstruction, Transcendent Justice, 92 Mich. L. Rev. 1131 (1994) (arguing that transcendental values arise from the wellsprings of the human soul), with Feldman, The Politics, supra note 4, at 192-201 (criticizing Balkin's argument).

${ }^{113}$ I have previously argued that "instead of contemplating and pursuing an affirmative vision of justice, we should focus on what might be called, deconjustice-an endless effort to eradicate injustice." Feldman, The Politics, supra note 4, at 200. From this perspective, "the deconstructive focus on the Other ought to be a central aspect of justice. The insatiable drive to reveal violence and deception, to uncover denial, exclusion, and oppression, should remain at the forefront of justice." ld.

${ }^{114}$ Cf. Gary Minda, Postmodern Legal Movements: Law and Jurisprudence at Century's End 248 (1995) (discussing a "postmodern temperament").

is Sunstein, Lochner, supra note 25 , at 905 . See generally Bernstein, supra note 7 , at 19 (discussing a "Cartesian Anxiety"); Jameson, supra note 7, at 11 (asserting that modernism has been called "the age of anxiety"). 
writer meanwhile uses postmodern insights as well as traditional modernist tools with irony. The postmodernist self-reflexively uses tools even as she recognizes that they cannot accomplish what she seeks. They always end up doing something else, going elsewhere, communicating some unintended meaning. ${ }^{116}$ But even with this recognition, the postmodernist uses the tools all the same, because that is the experience of postmodernism. In the words of Jean Baudrillard, "One plays ... with things that one doesn't believe in anymore."117

${ }^{116} \mathrm{Cf}$. Thiele, supra note 7 , at $225-26$ (in postmodernism, "[i]rony is always selfreferential"). Thiele notes that irony, like the perspectivist denial of epistemological and ethical foundations, is not unique to postmodernism. See id.

${ }^{11}$ Baudrillard, supra note 1, at 25. 
